\title{
Impacts of the Construction of the Port of Suape on Phytoplankton in the Ipojuca River Estuary (Pernambuco- Brazil)
}

\author{
Maria Luise Koening ${ }^{1 *}$, Enide Eskinazi Leça ${ }^{2}$, Sigrid Neumann-Leitão ${ }^{1}$ and Silvio José de \\ Macêdo ${ }^{1}$ \\ ${ }^{I}$ Department of Oceanography; Federal University of Pernambuco; Av. Arquitetura s/n; Cidade Universitária; \\ 50.670-901; Recife - Pernambuco - Brazil. ${ }^{2}$ Department of Biology; Federal Rural University of Pernambuco; Rua \\ Dom Manuel de Medeiros s/n; Dois Irmãos; 50171-030; Recife - Pernambuco - Brazil
}

\begin{abstract}
In order to address the impact on phytoplankton, sampling was conducted monthly at 4 fixed stations, from April/86 to March/87 at diurnal low and high tide using a plankton net (65 $\mu \mathrm{m}$ mesh size) and a $1 \mathrm{~L}$ Van Dorn bottle. Among the 133 taxa identified, marine littoral euryhaline species were most common, outranking Gyrosigma balticum (Ehrenberg) Rabenhorst, Nitzschia sigma (Kützing) Wm. Smith, Licmophora abbreviata Agardh, Climacosphenia moniligera Ehrenberg, Surirella febigerii Lewis, Terpsinoe musica Ehrenberg and Cylindrotheca closterium (Ehrenberg) Reiman and Lewis. The port construction caused significant changes to the phytoplankton community with a strong influence of marine species (mainly dinoflagellate) because of the opening of the reef near the river mouth in 1983. The shallow depth and hydrodynamic brought many littoral species to the water columm. The community was composed by marine euryhaline and limnetic organisms, influenced by the salinity, rain and tide. Species diversity was high (> 3 bits.cel $^{-1}$ ) owing to the high environmental heterogeneity (marine, freshwater and benthic interactions). After the port implantation, a strong decrease occurred in phytoplankton density owing to high loads of suspended matter. Lowest values $\left(121,00\right.$ cells. $\left.^{l-1}\right)$ were registered during rainy season. During dry season, when light intensity was higher, phytoplankton presented highest density $\left(1,789,000\right.$ cells. $\left.^{-1}\right)$.
\end{abstract}

Key words: Phytoplankton, environmental impacts, estuary, Suape Port

\section{INTRODUCTION}

The construction of an industrial port complex in the estuarine area of Suape in 1979/1984 caused great geomorphological, sedimentological and hydrodynamical changes. Major impacts such as the building of dams, embankments, channel construction and reefline openings occurred in the estuary of the Ipojuca River. (Neumann et al., 1998). The impact assessment, carried out by the Department of Oceanography of the Federal
University of Pernambuco, included hydrology and plankton studies (Neumann et al., 1998; Neumann Leitão and Matsura-Tundisi, 1998; Neumann- Leitão et al., 1999).

This paper characterizes the planktonic flora of the estuary of the Ipojuca River after the port construction in comparison with previous observed data (Eskinazi-Leça and Koening, 1985/86).

\footnotetext{
*Author for correspondence
} 


\section{DESCRIPTION OF THE AREA}

The estuary of the Ipojuca River with an hydrographic basin of $3,800 \mathrm{~km}^{2}$ is located nearly $40 \mathrm{~km}$ south of the city of Recife, Pernambuco State, within an area designated for the Industrial Complex $\left(08^{\circ} 15^{\prime} 00^{\prime \prime} \mathrm{S}-08^{\circ} 30^{\prime} 00^{\prime \prime} \mathrm{S} ; 3^{\circ} 55^{\prime} 00^{\prime \prime} \mathrm{W}\right.$ $\left.35^{\circ} 05^{\prime} 00^{\prime \prime} \mathrm{W}\right)$. The estuary extension is of approximately $15 \mathrm{~km}$, with a minimum depth of $0.80 \mathrm{~m}$ at low tide and maximum of $4.00 \mathrm{~m}$ at high tide. Salinity ranges between 0.05 and $36.00 \%$. The estuary receives a high load of sewage and wastes from 71 industries, mainly sugar cane processing factories and alcohol distilleries. The climate is warm, humid and pseudo-tropical (Köppen As'). Annual rainfall varies between 1,850 and $2,364 \mathrm{~mm}$, the dry season being from September to February and the rainy season from March to August. The average annual temperature and humidity is $24^{\circ} \mathrm{C}$ and higher than $80 \%$, respectively. Winds are generally from the southeast. The sand fill for the port implantation blocked the communication of the Ipojuca River with Suape Bay, damming the waters and causing floods in the backyard agricultural areas and degradation of mangroves. As a solution, in 1983 a partial opening $(250 \mathrm{~m}$ extension and depth of $80 \mathrm{~cm})$ in the reefline allows the water passage. Changes in the tidal cycles occurred with 4 hours of high tide and 8 hours of low tide. Sediment deposited in the Port area increased water turbidity, impacting directly on the primary productivity of the area. Water transparency was reduced during the rainy season with a minimum of $0.05 \mathrm{~m}$ and maximum of $2.00 \mathrm{~m}$ at dry season (Neumann-Leitão, 1994; Neumann et al., 1998).

The chemistry of the waters changed after the construction of the Port. Salinity was polihaline to limnetic (Cavalcanti et al., 1980) and changed to mesohaline/limnetic, except at the station closest to the reef where salinity remained $36 \%$. Concentrations of dissolved oxygen remained within normal average $\left(4,0 \mathrm{ml} / \mathrm{I}^{-1}\right)$. However, in the dry season (October to March and at low tide), polluted and semi-polluted zones continued to be detected in the internal areas of the estuary. The concentrations of nutrient salts varied along the whole year and increased gradually from the river mouth to internal area, being higher in the rainy season and at low tide (nitrate- $\mathrm{N}$ ranged from $0.003 \mu \mathrm{mol}^{-1^{-1}}$ to $46.170 \mu \mathrm{mol}^{-1} \mathrm{l}^{-1}$; phosphate-P from $0.071 \mu \mathrm{mol} .1^{-1}$ to $6.732 \mu \mathrm{mol} . \mathrm{l}^{-1}$ and silicate-Si from $9.305 \mu \mathrm{mol} . \mathrm{l}^{-1}$ to $276.251 \mu \mathrm{mol} . \mathrm{l}^{-1}$

\section{MATERIAL AND METHODS}

Phytoplankton samples were collected monthly during a tide cycle between April 1986 and March 1987 at 4 fixed stations (Fig. 1). A plankton net of mesh size $65 \mu \mathrm{m}$ and Van Dorn bottle were used for qualitative and quantitative analysis, respectively. After sampling, the material was fixed in 4\% neutral formaldehyde and lugol solution, respectively. Taxa identification was carried out under a standard microscope while the cells density was counted under an inverted microscope WILD-M40 according to Utermöhl (Hasle, 1978) with magnificances of 450X. The relative abundance and frequency of occurrence of each identified taxon were expressed in percentage; density expressed as number of cel. $1^{-1}$ and the specific diversity was calculated using the Shannon index (1948).

The multivariate analysis was performed using a matrix of species/samples, containing the relative abundance. Each matrix was submitted to cluster analysis, applying Pearson's moment-product correlation coefficient. The classification method used was the hierarchical agglomerate of "Proportional weight" (Weighted Pair Group Method - WPGM). For the species and environmental data were considered those species with more than $35 \%$ of frequency of occurrence. It was used the NTSYS (Numerical Taxonomy and Multivariate Analysis System) computer program of the Metagraphics Software Corporation, California - USA.

\section{RESULTS AND DISCUSSION}

\section{Cell Density}

Before the construction of the Port, total cell density varied from 416,000 cells. $^{-1}$ to $5,748,000$ cells. $1^{-1}$ (Koening and Eskinazi-Leça, 1991). After the Port implantation, there was a strong decrease in phytoplankton density owing to the high loads of suspended material, and probably light limitation. 


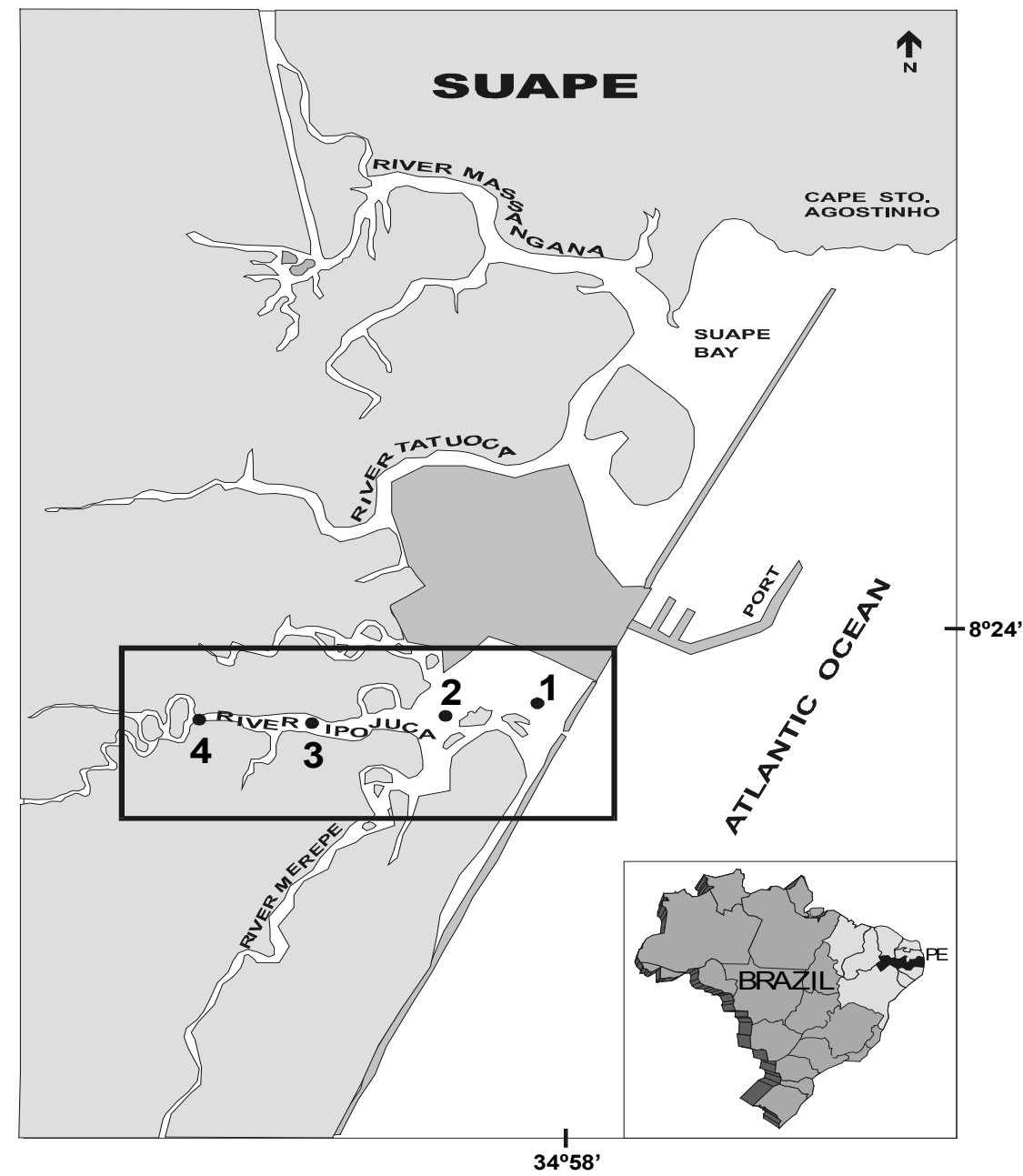

Figure 1 - Suape area and sampling stations.

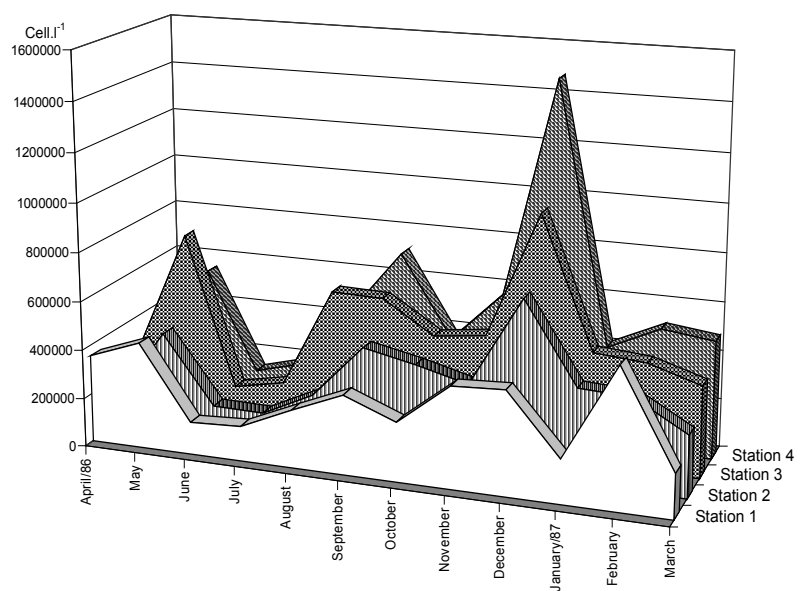

Figure 2 - Phytoplankton density in the Ipojuca River Estuary (Suape-PE-Brazil) 
Low values (minimum of 121,000 cells..$^{-1}$ ) were registered in the rainy season, in spite of high nutrient avalability. In the dry season, when light intensity was higher, phytoplankton presented density maximum $\left(1,474,000\right.$ cells..$\left.^{-1}\right)$ with low nutrients (Fig. 2).

Species composition

Before the construction of the Port, 68 species of microalgae $(60$ species of diatoms, 5 of chlorophyceans and 3 of cyanophyceans) were registered (Eskinazi-Leça and Koening, 1985/86). The construction of the Port of Suape seemed to have altered the structure of the phytoplankton community in the estuary of the Ipojuca River, not only regarding the appearance of a greater number of species, but also in relation to the ecological. community characteristics. One hundred and thirty-three species were identified in our study: 80 species of diatoms, 28 of chlorophyceans, 12 of dinoflagellates, 7 of cyanophyceans and 6 of euglenophyceans (Table 1). These species number decreased from the station closer to the reefline to upstream. The reefline opening allowed seawater penetration and the presence of several dinoflagellate species (station 1). The high quantity of suspended material in the estuary favored the development of euglenophyceans, while considerable rainfall during the study year, contributed to the increase of chlorophyceans. The cyanophyceans, usually associated with fresh water habitats, were present in all stations. Diatoms predominated along the whole estuary, making up more than $60 \%$ of the planktonic flora. The increase in diatom species closer to the reef was due to higher salinity and nutrient concentrations, conditions favorable to the development of eurihaline diatom species. According to Levinton (1995), estuarine environments are characterized by abundant populations of few dominant species due to the great environmental variability. In the estuary of the Ipojuca River, although there was a considerable number of identified species, few of them presented high abundance: Chaetoceros lorenzianus, Climacosphenia moniligera, Cylindrotheca closterium, Gyrosigma balticum, Nitzschia sigma, Skeletonema costatum, Surirella febigerii, Terpsinoe musica and Oscillatoria tenuis. Two species (Gyrosigma balticum and Nitzschia sigma), were found in all stations and months, while most species presented low frequency. Before the Port construction, the marine dominant planktonic species were
Biddulphia regia, Coscinodiscus centralis, Coscinodiscus granii, Chaetoceros lorenzianus, Chaetoceros curvisetus, Leptocylindrus danicus and Skeletonema costatum (Eskinazi-Leça and Koening, 1985/86). After the port construction, changes in the tidal cycle and in the circulation pattern caused a vertical mixing resuspending sediments together with littoral species Climacosphenia moniligera, Gyrosigma balticum, Licmophora abbreviata, Nitzschia sigma, Surirella febigerii and Terpsinoe musica.

\section{Diversity and evenness indexes}

Species diversity and evenness were high, demonstrating a relatively homogeneous distribution of species. The environmental instability, represented by various allogenic and endogenous factors, contributed to a environmental heterogeneity allowing presence of a diversified community increasing the number of niches and the incidence of species previously uncommon in the area. In some cases, high diversity was due to specialized species (kstrategists) or opportunists (r-strategists). In the last case it meant that levels of disturbance were affecting the ecosystem health (New,1995).

The specific diversity was around 3.0 bits.cel..$^{-1}$. Low value $\left(<2.0\right.$ bits.cel..$\left.^{-1}\right)$ was caused by a bloom of Skeletonema costatum and Oscillatoria tenuis, which presented a relative abundance higher than $60 \%$. The evenness oscillated between 0.4 and 0.9 (Figs. 3 and 4).

\section{Sample Clustering}

The cluster analysis of the samples showed three main groups (Fig. 5).

Group 1: all samples of the four stations gathered during the rainy season were clustered, including high and low tide, coinciding with the highest precipitation and lowest salinity. Due to precipitation, the influence of fresh water was observed up to the station closest to the reef (station 1).

Group 2: clustered samples from the dry season, and low and high tides of the four stations (flux of fresh water).

Group 3: included mainly the samples of station 1 with marine characteristics (high tide). 

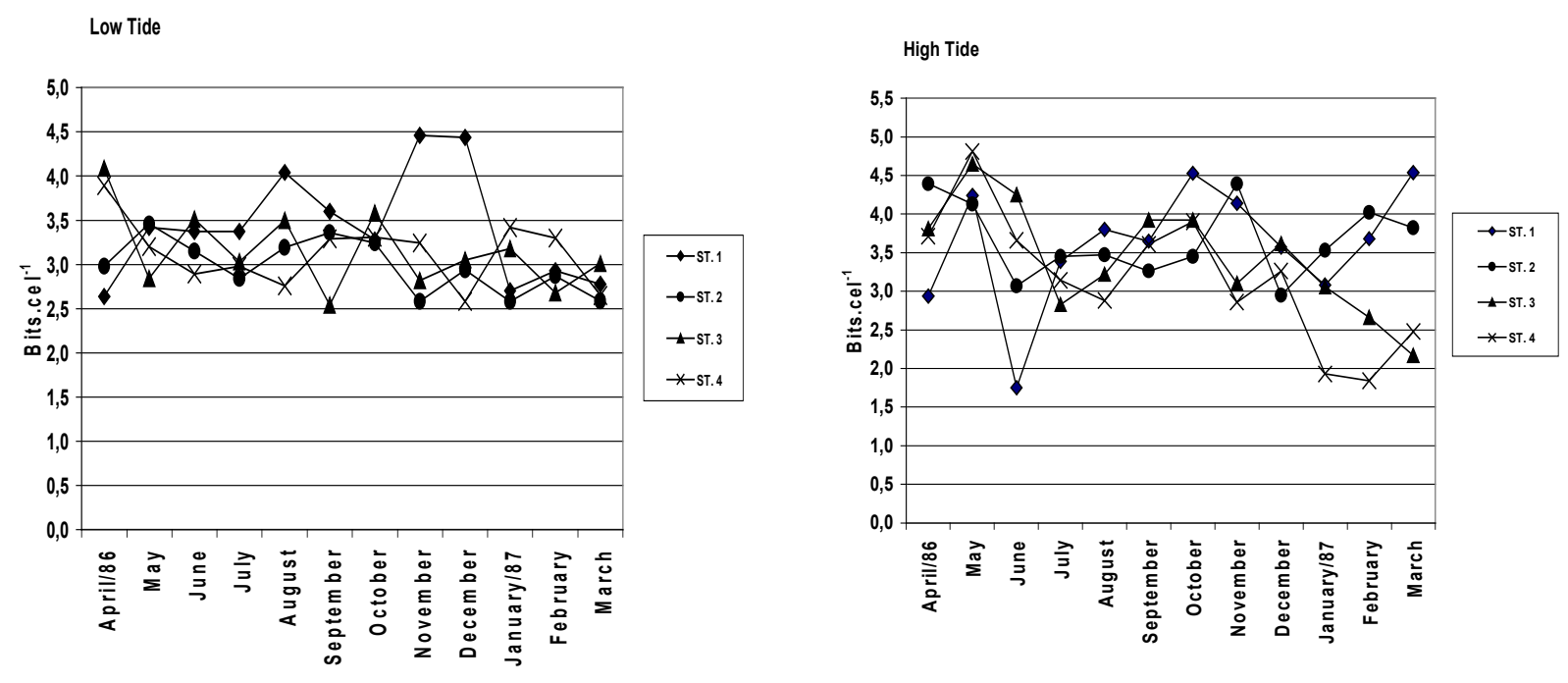

Figure 3 - Diversity of species in the Ipojuca River Estuary (Suape-PE-Brazil)
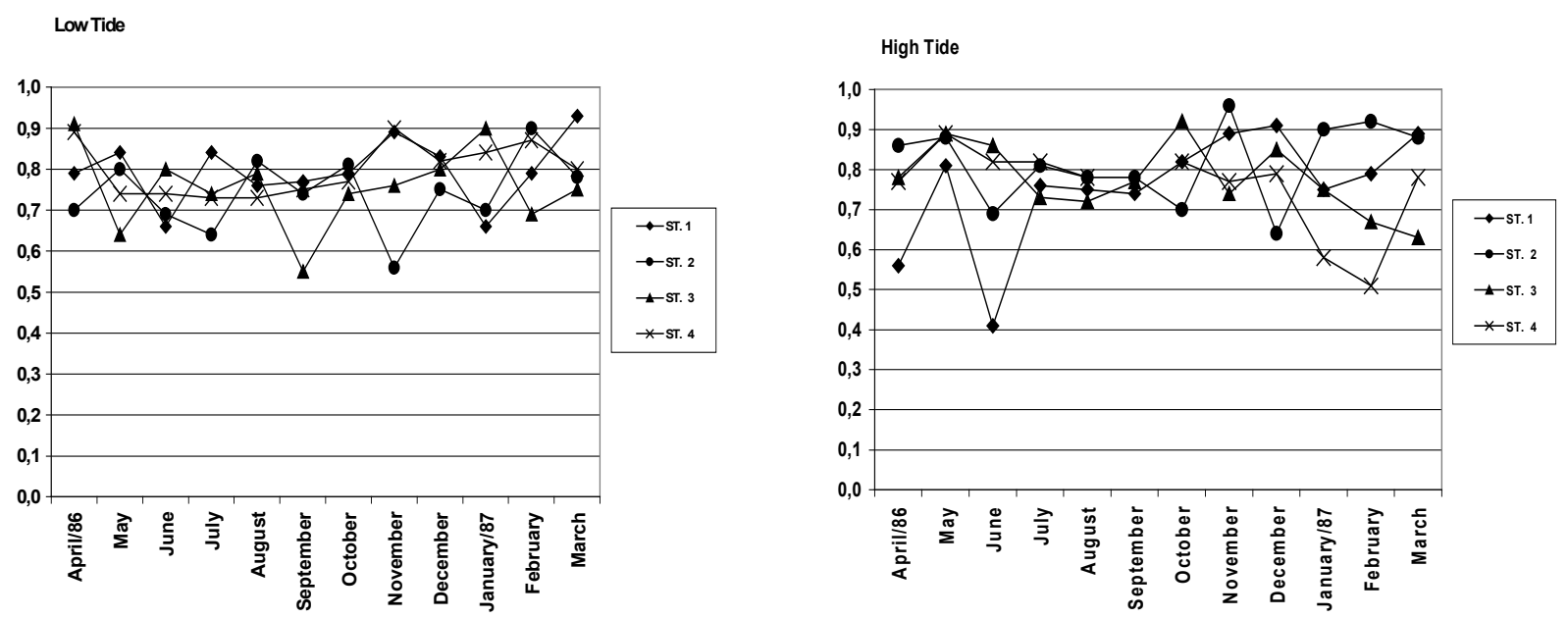

Figure 4 - Evenness in the Ipojuca River estuary (Suape-PE-Brazil) 
Table 1 - Phytoplankton composition in the Ipojuca River Estuary (Suape-PE-Brazil).

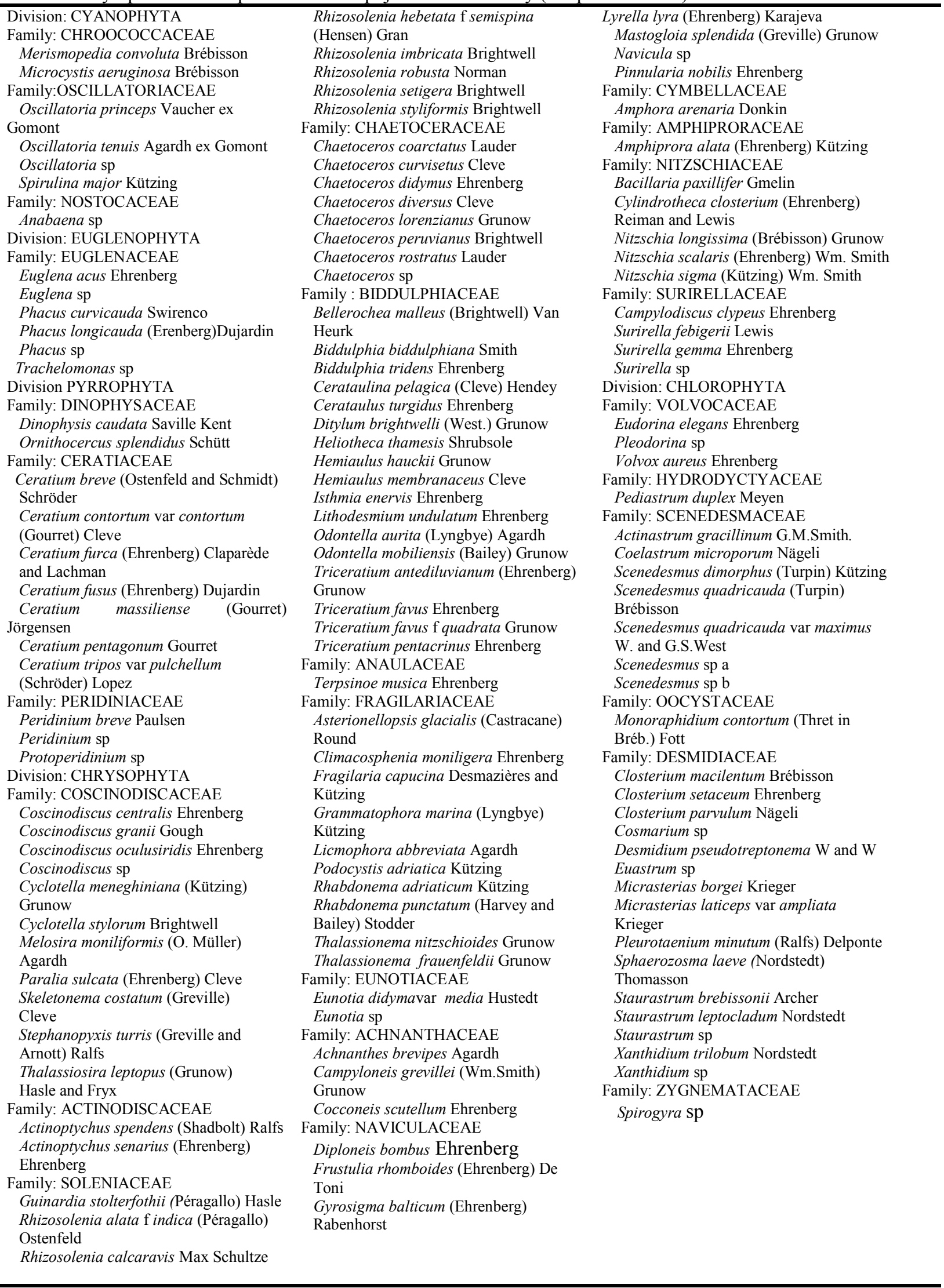




$\begin{array}{cccc}-1,00 & -0,60 & -0,20 & 0,20 \\ & 1,00 & \end{array}$

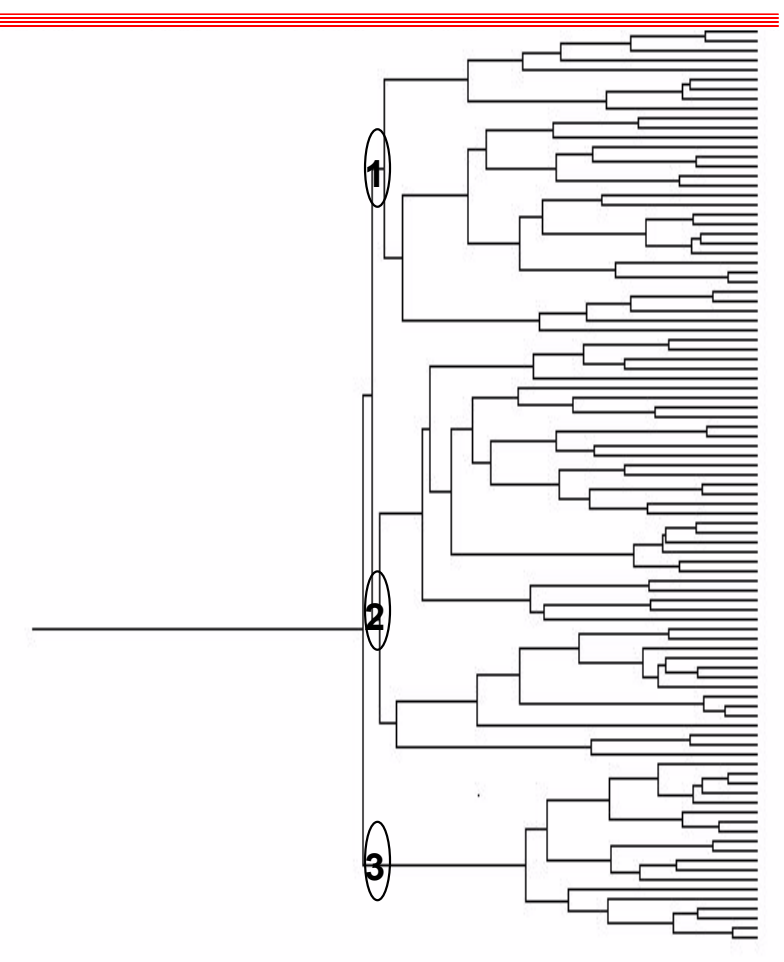

$-1,00$

$-1,00$
0,6C GROUP 1: S1 LT APR; S4 HT APR; S1 LT MAY; S2 LT MAY; S2 LT APR; S2 LT JUN; S3 LT AUG; S2 HT JUL; S2 LT AUG; S1 LT JUN; S1 LT AUG; S3 LT JUN; S1 LT JUL; S3 LT JUL; S4 LT JUL; S1 HT JUL; S3 HT APR; S1 HT JUN; S2 LT JUL; S3 HT JUN; S3 HT JUL; S4 HT JUN; S4 HT JUL; S4 LT AUG; S3 HT MAY; S4 HT MAY; S4 LT JUN; S2 HT MAR; S3 HT MAR; S3 LT APR; S4 LT APR; S4 HT OCT.

GRUP 2: S1 LT SEP; S3 LT NOV; S2 HT AUG; S2 LT DEC; S2 LT OCT; S1 LT OCT; S1 LT NOV; S1 LT DEC; S2 HT NOV; S1 LT JAN; S2 HT DEC; S2 HT JAN; S3 HT JAN; S2 LT SEP; S3 LT OCT; S2 LT NOV; S2 LT JAN; S4 LT NOV; S4 LT FEB; S1 LT FEB; S3 LT JAN; S3 LT FEB; S1 LT MAR; S3 HT DEC; S4 LT JAN; S3 HT SEP; S4 LT OCT; S3 HT NOV; S4 HT DEC; S3 LT DEC; S2 HT JUN; S3 HT AUG; S2 LT MAR; S3 HT FEB; S4 LT MAR; S4 HT MAR; S4 LT DEC; S3 HT OCT; S4 HT NOV; S4 HT JAN; S3 LT MAR; S3 LT FEB; S4 HT FEB; S4 HT AUG

GRUP 3: S1 HT APR; S1 HT SEP; S1 HT FEB; S1 HT MAR; S1 HT DEC; S1 HT OCT; S1 HT NOV; S1 HT JAN; S1 HT MAY; S2 HT APR; S2 HT MAY; S4 LT MAY; S3 LT MAY; S1 HT AUG; S2 HT SEP; S2 HT OCT; S2 HT FEB; S3 LT SEP; S4 LT SEP. $\mathrm{S}=$ STATION HT $=$ HIGH TIDE LT $=$ LOW TIDE

Figure 5 - Dendrogram showing the similarities of groups of stations in the Ipojuca River Estuary (Suape-PE-Brazil).

\section{Species Clustering}

Clustering among three groups is evident (Fig. 6).

Group 1: This group was related to the marine flux, with higher concentrations of dissolved oxygen, transparency, salinity, $\mathrm{pH}$ and higher species diversity. In this group, Euglena acus, Chaetoceros lorenzianus, Bacillaria paradoxa and Campylodiscus clypeus were clustered.

Group 2: This was the biggest group, mainly constituted by phytoplankton species frequently found in estuarine environments with high concentration of chlorophyll- $a$ and nutrients, which are partly brought in by the river and partly produced in the ecosystem itself. In this group, following species were clustered: Coscinodiscus oculusiridis, Scenedesmus quadricauda, Nitzschia sigma, Coscinodiscus sp., Terpsinoe musica, Pinnularia nobilis, Surirella febigerii, Melosira moniliformis, Nitzschia scalaris and Gyrosigma balticum. Some of these species occured practically in all months of the studied period at 
the four stations (Gyrosigma balticum, Nitzschia sigma, Surirella febigerii and Terpsinoe musica).

Group 3 : The species in this group were related to a greater biochemical demand of oxygen and occured mainly during the dry season, when there was a higher demand of polluting agents coinciding with low quantities of dissolved oxygen. They were typical anoxic areas influenced by mangroves. In this group, only Cylindrotheca closterium, Nitzschia longissima and not identified diatoms were clustered.

Even though the estuarine environment has high resilience, the impacts in the area of Suape were so pronounced that they caused changes in the ecosystem and related communities. The structure of the phytoplanktonic community was presently composed of littoral and fresh water species, besides a strong decrease in cell density when compared to studies before the port implantation (Koening and Eskinazi-Leça, 1991).

\section{RESUMO}

A implantação do Complexo Industrial Portuário de Suape (Pernambuco-Brasil) entre 1979 e 1984, modificou os processos ecológicos observados no estuário do rio Ipojuca. As amostras foram coletadas mensalmente em 4 estações fixas, no período de abril/86 a março/87 nas preamares e baixa-mares diurnas, utilizando-se uma rede de plâncton com abertura de malha de $65 \mu \mathrm{m}$ e garrafas de Van Dorn. Foram identificados um total de 133 taxa. As espécies marinhas litorais foram as mais comuns e freqüentes, destacando-se: Gyrosigma balticum (Ehrenberg) Rabenhorst, Nitzschia sigma (Kützing) Wm. Smith, Licmophora abbreviata Agardh, Climacosphenia moniligera Ehrenberg, Surirella febigerii Lewis, Terpsinoe musica Ehrenberg and Cylindrotheca closterium (Ehrenberg) Reiman and Lewis. A composição florística do fitoplâncton mostrou diferenças significativas após a construção do Porto, tendo ocorrido uma maior representação de espécies marinhas, principalmente de dinoflagelados, as quais, com a abertura dos recifes foram mais facilmente carreadas para 0 estuário. A flora esteve caracterizada por espécies litorais, que em virtude da pequena profundidade e aumento do hidrodinamismo, chegam à camada superficial da coluna da água. A comunidade fitoplanctônica está influenciada pela salinidade, precipitação pluviométrica e variações de marés. Devido à interação de diversos fluxos, a diversidade específica foi elevada ( $>3$ bits.cel $\left.^{-1}\right)$, demonstrando haver uma heterogeneidade ambiental. Após a construção do Porto, foi verificado uma diminuição da densidade fitoplanctônica devido à grande quantidade de material em suspensão, sendo a luz o fator limitante. Os menores valores foram registrados no período chuvoso (121.000 cel. $\left.\mathrm{l}^{-1}\right)$, apesar das concentrações elevadas de nutrientes. No período seco, quando a intensidade luminosa é mais intensa, o fitoplâncton apresenta as maiores densidades $\left(1.789 .000\right.$ cel. $\left.1^{-1}\right)$. 


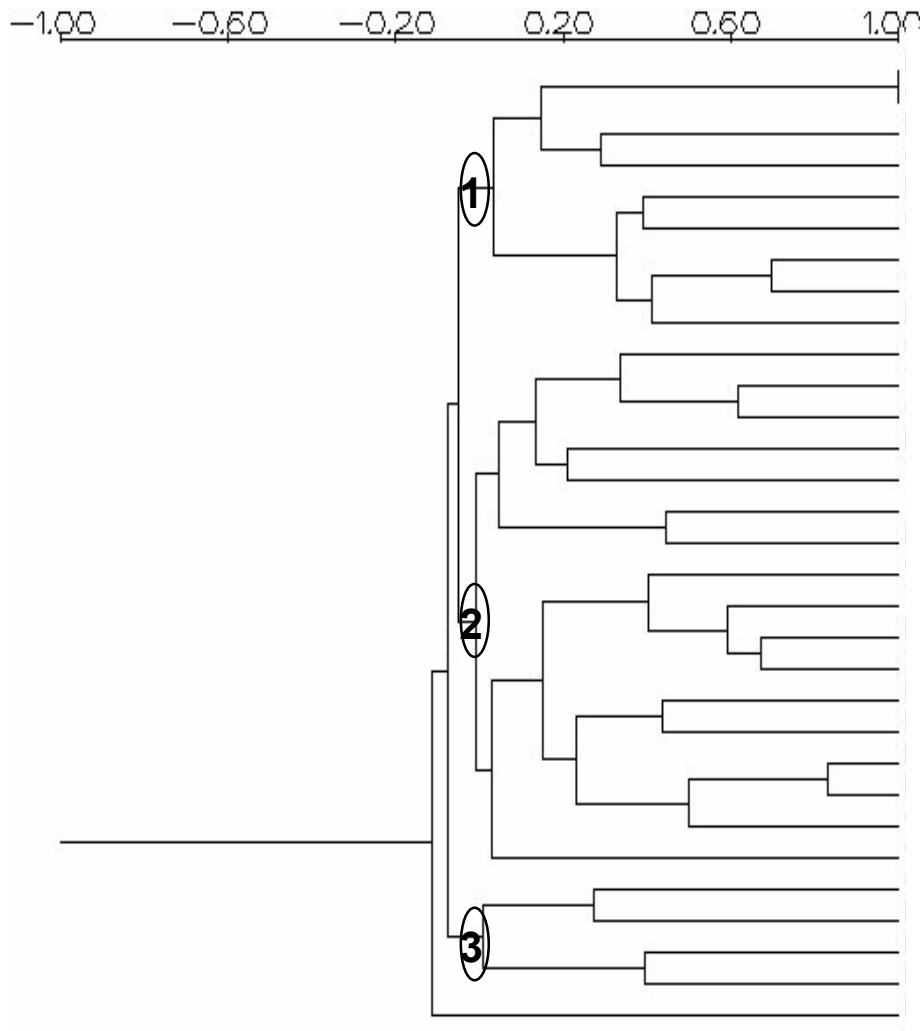

Euglena acus
Chaetoceros lorenzianus
Bacillaria paxillifer
Campylodiscus clypeus
Species diversity
Dissolved oxygen
Transparence
Salinity
pH
Coscinodiscus oculusiridis
Scenedesmus quadricauda
Chlorophyceae (no identified)
Nitzschia sigma
Silicate
Temperature
Phosphate
Coscinodiscus sp
Terpsinoe musica
Pinnularia nobilis
Surirella febigerii
Melosira moniliformis
Nitzschia scalaris
Nitrite
Nitrate
Chlorophyll a
Gyrosigma balticum
Cylindrotheca closterium
Biochemical Oxygen Demand
Nitzschia longissima
Diatom (no identified)
Rhizosolenia setigera

Figure 6 - Dendrogram of the species clustering of phytoplankton with more than 35\% frequency of occurence and environmental parameters in the Ipojuca River Estuary (Suape-PEBrazil).

\section{REFERENCES}

Cavalcanti, L. B.; Coelho, P. A.; Eskinazi-Leça, E.; Luna, J. A. C.; Macêdo, S. J. and Paranaguá, M. N. (1980), Condiciones ecológicas en el area de Suape (Pernambuco-Brasil). In: Seminario sobre el estudio cientifico e impacto humano en el ecossistema de manglares, 1978, Cali. Memorias... Montevideo : UNESCO, Oficina Regional de Ciência y Tecnologia para a America Latina y el Caribe. pp. 243-256.

Eskinazi-Leça, E. and Koening, M. L. (1985/86), Distribuição das diatomáceas (Bacillariophyceae) na área de Suape (Pernambuco-Brasil). Trab. Oceanog. Univ. Fed. PE, 19, 73-100.

Koening, M. L. and Eskinazi-Leça, E. (1991), Aspectos quantitativos na área de Suape. In: Encontro Brasileiro de Plâncton, 4, Recife, pp. 55-60.

Levinton, J. S. (1995), Marine biology: function, biodiversity, ecology. New York : Oxford University Press. pp.1-420.

Neumann-Leitão, S. (1994), Impactos antrópicos na comunidade zooplanctônica estuarina. Porto de Suape-PE-Brasil. São Carlos. Tese (Doutorado em Ciências da Engenharia Ambiental) - Departamento de Hidráulica, Escola de Engenharia de São Carlos da Universidade de São Paulo. 273 f.
Neumann-Leitão, S. and Matsumura-Tundisi, T. (1998), Dynamics of a perturbed estuarine zooplnktonic community: Port of Suape, PE, Brazil. Verh. Internat. Verein. Limnol., 26, 1981-1988.

Neumann-Leitão, S.; Koening, M. L.; Macêdo, S. J.; Medeiros, C.; Muniz, K. and Feitosa, F. A. N. (1999), Plankton disturbance at Suape estuarine areaPernambuco-Brazil after a Port Complex implantation. Second International Conference on Ecosystems and Sustainable Development. In: Usó, J. L. and Brebbia, C. A. (ed.). Greece. WIT Press, Boston, 2, 47-56.

Neumann, V. H.; Medeiros, C.; Parente, L.; NeumannLeitão, S. and Koening, M. L. (1998), Hydrodynamism, sedimentology, geomorphology and plankton changes at Suape area (Pernambuco-Brazil) after a Port Complex Implantation. An.Acad. Bras. Ci., 70 : (2); 313-323.

New, T. R. (1995), An introduction to invertebrate conservation biology. Oxford University Press. 194 pp.

Shannon, C. E. (1948), A mathematical theory of communication. Bulletin of System Tecnology Journal, 27379-423.

Received: January 04, 2001; Revised: May 31, 2001, Accepted: October 11, 2001. 